\title{
Association between interleukin-8 receptor- $\alpha$ (CXCR1) polymorphism and disease incidence, production, reproduction, and survival in Holstein cows
}

\author{
K. N. Galvão, ${ }^{1}$ G. M. Pighetti, S. H. Cheong, D. V. Nydam, and R. O. Gilbert ${ }^{2}$ \\ Department of Clinical Sciences, Cornell University, Ithaca, NY 14853
}

\begin{abstract}
The objective was to evaluate the association between the single nucleotide polymorphism at position +735 in the interleukin-8 receptor- $\alpha$ (CXCR1) gene (CXCR1c.735) and disease incidence, milk production, reproductive performance, and survival in Holstein cows. Three-hundred fifty Holstein cows were enrolled. No association was found between CXCR1c.735 genotype and retained fetal membranes, metritis, or endometritis. Incidence rate of clinical mastitis was associated with CXCR1c.735 genotype; cows with genotypes CC and GC had a decreased incidence rate of clinical mastitis compared with GG cows. Milk yield was associated with CXCR1c.735 genotype; cows with genotype GC had greater milk yield than GG cows. Hazard of pregnancy was not associated with CXCR1c.735 genotype. Cows that had clinical mastitis had decreased hazard of pregnancy, and cows that had endometritis tended to have a decreased hazard of pregnancy. Hazard of death or culling was not associated with CXCR1c.735 genotype. Multiparous cows and cows that had mastitis had increased hazard of death or culling. In contrast to what we expected, cows with the genotype GG had an increased incidence rate of clinical mastitis and decreased milk yield.
\end{abstract}

Key words: metritis, endometritis, mastitis, single nucleotide polymorphism

\section{INTRODUCTION}

Recently, SNP in the neutrophil IL-8 receptor were identified (Youngerman et al., 2004a) and cows with the genotype CC had increased incidence of subclinical mastitis (Youngerman et al., 2004b). Subclinical mastitis was defined as the presence of the same pathogen in the same quarter in at least 2 of 3 consecutive

\footnotetext{
Received June 20, 2010.

Accepted December 2, 2010.

${ }^{1}$ Current address: Department of Large Animal Clinical Sciences, College of Veterinary Medicine, University of Florida, Gainesville 32610 .

${ }^{2}$ Corresponding author: rob.gilbert@cornell.edu
}

samples. Initially, the G > C SNP was reported in the IL-8 receptor- $\beta$ (CXCR2) gene (Youngerman et al., 2004b), but after closer investigation it was discovered the gene was misannotated and was actually the IL-8 receptor- $\alpha$ (CXCR1) gene (Pighetti and Rambeaud, 2006). Earlier nomenclature also placed this nonsynonymous SNP at position +777 relative to the published sequence (GenBank accession no. U19947). However, when using practices recommended by the Human Genome Variation Society for naming SNP (den Dunnen and Antonarakis, 2000), the SNP is located at CXCR1 c. +735 (CXCR1c.735) relative to the A of the ATG translation initiation start site (GenBank accession no. NM_001105038.1). Cows can inherit the altered sequence in both (CC), one (GC), or neither (GG) of the alleles. The substitution of nucleotide $\mathrm{G}$ with $\mathrm{C}$ results in a glutamine to histidine substitution at AA position 245 within the third intracellular loop of the CXCR1 protein. This is located near the G-protein binding site and has the potential to interfere with signaling (Damaj et al., 1996). In fact, neutrophils from cows with the genotype $\mathrm{CC}$ had decreased receptor affinity to IL-8, decreased calcium signaling, lower adhesion molecule expression, impaired migration, and decreased generation of reactive oxygen species (Rambeaud and Pighetti, 2005, 2007; Rambeaud et al., 2006). Neutrophil function, such as generation of reactive oxygen species, and survival were intermediate for cows with the genotype GC compared with those with $\mathrm{CC}$ and GG (Rambeaud et al., 2006). Migration toward IL-8 but not zymosan-activated serum was impaired for the genotype GC compared with genotype GG (Rambeaud and Pighetti, 2005).

Neutrophils are the main leukocyte type involved in placental release (Kimura et al., 2002), and in bacterial clearance after uterine (Hussain, 1989) and mammary gland (Paape et al., 2002) infection. Cows with retained fetal membranes present reduced neutrophil migration to sites of placental attachment (Kimura et al., 2002), cows with the greatest influx of neutrophils into the uterus have reduced risk of bacterial infection and reduced incidence of endometritis (Gilbert et al., 2007), and migration of neutrophils into the mammary 
gland is essential for clearance of mastitis pathogens (Paape et al., 2000). Interleukin-8 is the main chemoattractant for neutrophils; binding of IL-8 to its receptors (CXCR1 and CXCR2) in the neutrophil induces neutrophil activation, stimulates chemotaxis, and increases phagocytosis and killing ability (Mitchell et al., 2003).

The hypothesis was that dairy cows with the genotype CC or GC at CXCR1c.735 would have increased incidence of retained fetal membranes, metritis, endometritis, and mastitis. Therefore, the objective was to genotype cows for the CXCR1c.735 (GG, GC, or $\mathrm{CC}$ ) SNP and compare the incidence of retained fetal membranes, incidence of metritis, the prevalence of endometritis, and incidence of mastitis among cows with different genotypes. Because uterine diseases and mastitis can affect reproductive performance, milk yield, and cow survival, those outcomes were also evaluated.

\section{MATERIALS AND METHODS}

\section{Animals, Housing, and Feeding}

Three hundred fifty cows (147 primiparous and 203 multiparous) from 23 commercial Holstein dairy farms located in New York State were used in the study. Cows used for this study were also part of 1 of 2 other studies (Galvão et al., 2010; Cheong et al., 2011). Herd sizes ranged from 500 to 3,000 cows. Ten to 20 cows were used from each of the 22 herds from the study by Cheong et al. (2011) and 80 cows were used from a single herd from the study by Galvão et al. (2010). All the herds were enrolled in DHIA (Ithaca, NY); therefore, monthly milk weights, milk components (fat and protein), and SCC were available from the herd management software Dairy Comp 305 (ValleyAg Software, Tulare, CA) and were retrieved at the end of the study for statistical analysis. The rolling herd averages were approximately $11,500 \mathrm{~kg}$ of milk. Primiparous and multiparous cows were housed separately in freestall facilities in all herds. All cows were fed a TMR formulated to meet or exceed the NRC (2001) nutrient requirements for lactating Holstein cows weighing $680 \mathrm{~kg}$ and producing $45 \mathrm{~kg}$ of $3.5 \%$ FCM. All cows were examined by the herd veterinarian for pregnancy by palpation per rectum at $38 \pm$ $3 \mathrm{~d}$ after AI, and all pregnant cows had the pregnancy confirmed before dry-off (around $200 \mathrm{~d}$ after AI). Cows diagnosed pregnant at $38 \mathrm{~d}$ after $\mathrm{AI}$ and then diagnosed not pregnant at or before dry-off were considered to have aborted the pregnancy.

\section{Blood Sample Collection, DNA Isolation, and CXCR1 Genotyping}

All cows had a blood sample collected between 40 and 60 DIM by puncture of coccygeal vessels into Va- cutainer tubes (Becton Dickinson, Franklin Lake, NJ) containing EDTA as anticoagulant. The samples were immediately placed on ice and transported to the laboratory within $4 \mathrm{~h}$, frozen at $-80^{\circ} \mathrm{C}$, and then submitted to the DNA bank at Cornell University (Ithaca, NY) for DNA isolation. Genomic DNA was purified from $200 \mu \mathrm{L}$ of whole, previously frozen blood following the manufacturer's instructions (UltraClean BloodSpin Kit, cat. no. 12200-50, MoBio Laboratories, Carlsbad, CA). Purified genomic DNA was diluted $10 \times$ in moleculargrade water. One microliter of that DNA (13-70 ng) was used in PCR with primers p106 F (5'CTTCCGTGAGGCCTATCAAC) and p107 R (5'AGGTCTCAGCAATCACATGG) in a $20-\mu \mathrm{L}$ total volume reaction mix containing $0.5 \mathrm{U}$ of Taq polymerase (GoTaq Flexi, cat no. M8291, Promega, Madison, WI), $2 \mathrm{mM} \mathrm{MgCl}$, $0.2 \mathrm{~m} M$ of each dNTP, and $0.2 \mu M$ of each primer in $1 \times$ green GoTaq Flexi buffer (Promega). To specifically amplify the 311-bp fragment of bovine CXCR1 containing the SNP of interest, the following cycling parameters were used: (1) $95^{\circ} \mathrm{C}$ for $2 \mathrm{~min},(2) 95^{\circ} \mathrm{C}$ for $15 \mathrm{~s},(3) 56^{\circ} \mathrm{C}$ for $15 \mathrm{~s},(4) 72^{\circ} \mathrm{C}$ for $30 \mathrm{~s}$, with steps (2) to (4) repeated 40 times; (5) $72^{\circ} \mathrm{C} 10 \mathrm{~min}, 4^{\circ} \mathrm{C}$ hold (Mastercycler gradient, Eppendorf). Products of the PCR were digested with BaeGI (New England Biolabs, Ipswich, MA, cat no. R0708S) in a total volume of $40 \mu \mathrm{L}$ (reaction mix components: $20-\mu \mathrm{L}$ PCR mix, $1 \times$ NEB buffer $1,2 \mathrm{U}$ of BaeGI enzyme). After $4 \mathrm{~h}$ of incubation at $37^{\circ} \mathrm{C}, 10 \mu \mathrm{L}$ of each sample was run on $2 \%$ agarose gel (large slab, $180 \mathrm{~V}$, approximately $45 \mathrm{~min}$ ). The digestion resulted in products of 291 and $20 \mathrm{bp}$ for the $\mathrm{G}$ allele and 189, 102 , and $20 \mathrm{bp}$ for the $\mathrm{C}$ allele, allowing genotyping of each animal for the SNP of interest (Figure 1).

\section{Evaluation of Uterine Diseases and Mastitis}

Cows were evaluated $24 \mathrm{~h}$ after calving for presence of retained fetal membranes (RFM); cows that had not released the fetal membranes were classified as having retained the placenta. Cows were evaluated daily for signs of metritis in the first 14 DIM by the herd personnel and one of the coauthors in the study by Galvão et al. (2010) and by the herd personnel in the study by Cheong et al. (2011). Metritis was characterized by the presence of watery, fetid vaginal discharge and rectal temperature $>39.5^{\circ} \mathrm{C}$. Between 40 and 60 DIM, cows had a low-volume uterine lavage for diagnosis of endometritis (END) based on the proportion of neutrophils out of a total of 200 cells, including all leukocyte types and epithelial cells but excluding erythrocytes, as described previously (Gilbert et al., 2005). The proportion of neutrophils used as cut-off for classifying cows as having endometritis was determined using receiver operating characteristic analysis as previously reported 


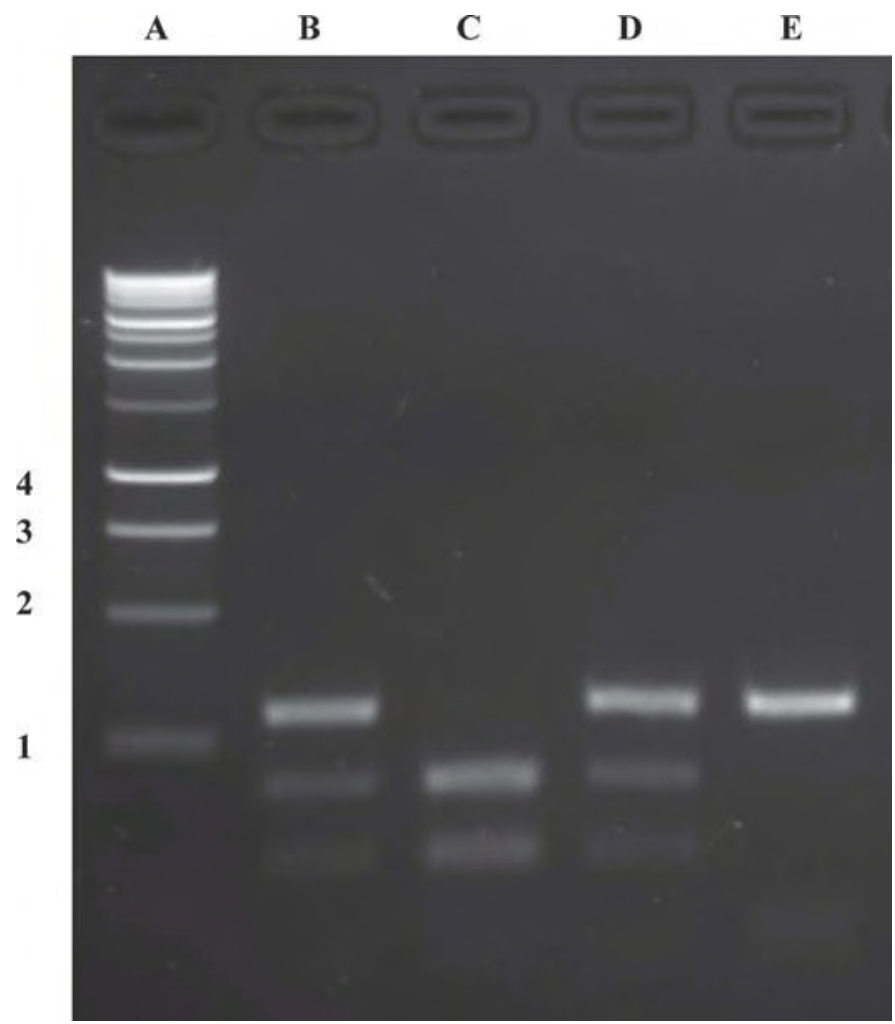

Figure 1. Agarose gel (2\%) used for genotyping a SNP (CXCR1c.735) in the IL-8 receptor- $\alpha$ gene (CXCR1). The digestion resulted in products of 291 and 20 bp for allele $\mathrm{G}$, and 189, 102, and $20 \mathrm{bp}$ for allele C. Lane A) Marker (1-kb DNA Ladder, Promega, Madison, WI: $1=250 \mathrm{bp}, 2=500 \mathrm{bp}, 3=750 \mathrm{bp}, 4=1,000 \mathrm{bp}$ ); lane B) CXCR1c.735 GC; lane C) CXCR1c.735 CC; lane D) CXCR1c.735 GC; and lane E) CXCR1c.735 GG. Note that the 20-bp fragments are not visible in this image.

(Kasimanickam et al., 2004) and found to be $10 \%$, consistent with the recommendation of Sheldon et al. (2006). Clinical mastitis was diagnosed during the whole lactation by the herd personnel as part of the milking procedure in all farms. Clinical mastitis was characterized by presence of abnormal milk (presence of flakes or clots, or discolored or watery milk) or abnormal udder (swollen or hard quarters). Cases of RFM, metritis, and clinical mastitis were entered in the herd management software (Dairy Comp 305) and retrieved at the end of the study for statistical analysis.

\section{Statistical Analyses}

This was an observational cohort study. Associations between RFM, metritis, END, and mastitis were evaluated by chi-squared test using the FREQ procedure in SAS (version 9.1; SAS Institute Inc., Cary, NC). Association between CXCR1c.735 genotypes (CC, $\mathrm{GC}$, or GG) and dichotomous outcomes such as RFM, metritis, and END was evaluated by mixed logistic regression using PROC GLIMMIX of SAS (version 9.1,
SAS Institute Inc.). The model for RFM included the fixed effects of CXCR1 genotypes, parity (primiparous or multiparous), interaction between CXCR1 and parity, and herd as a random effect. The model for metritis also included the fixed effect of RFM (yes or no), and the model for END also included the fixed effect of metritis (yes or no).

Effect of CXCR1 genotypes on incidence rate of clinical mastitis was evaluated using a mixed-effects Poisson regression model using the XTMEPOISSON procedure in Stata (StataCorp LP, College Station, TX; Rabe-Hesketh and Skrondal, 2008). The model included the fixed effects of CXCR1 genotype, parity, RFM, metritis, END, interactions between CXCR1 genotypes and other covariates, and herd as a random effect. The exposure variable was the natural logarithm of the number of cow-days at risk. Cow-days at risk were calculated as the total number of days in lactation minus $14 \mathrm{~d}$ after each case of clinical mastitis. Intervals between cases had to be $>14 \mathrm{~d}$ for a case to be included in the analysis. The incidence rate of clinical mastitis was expressed as the number of cases per 10,000 cowdays at risk.

Continuous outcomes such as milk yield and SCC were analyzed by ANOVA for repeated measures using the MIXED procedure (SAS Institute Inc.). Models included the fixed effects of CXCR1c.735 genotype, parity, RFM, metritis, END, mastitis (yes or no), time (monthly milk test number: 1 to 10), and 2-way interactions between CXCR1 and other covariates. Herd and cow were random effects (cow nested within herd). Because all the outcomes evaluated were biological samples collected at even intervals, a first-order autoregressive covariance structure was used. When a main effect was observed, post hoc multiple comparisons were performed using the Bonferroni adjustments in SAS. Evaluation of normality of the residuals was performed in Minitab (version 15; Minitab Inc., State College, PA) by inspection of standardized residuals plotted against predicted values for the residuals using the regression option in Minitab. Residuals fit to a normal distribution were also evaluated. Standardized residuals for milk were normally distributed; however, raw data for SCC was transformed to their natural logarithm (lnSCC) to achieve normality. After statistical analysis, transformed data were back-transformed to report least squares means.

The hazard of pregnancy and the hazard of death or culling were analyzed by shared frailty survival models (Gutierrez, 2002) using the STREG procedure in Stata. Results are presented as hazard ratios (HR). The hazard ratio is the conditional daily probability of a given event (pregnancy or death/cull) and may be interpreted as the pregnancy rate or death/cull rate (speed 
at which cows become pregnant or die/are culled). The time variable for the hazard of pregnancy was the days between calving and pregnancy, which was detected 38 $\pm 3 \mathrm{~d}$ after AI. Cows that were not pregnant by 305 DIM, died, or were culled were censored in the analysis of hazard of pregnancy. Cows that were not dead or culled by 525 DIM and cows that were dried off were censored in the analysis of hazard or death/cull. The interval of $305 \mathrm{~d}$ for hazard of pregnancy was chosen because that is considered a normal lactation length and because that is typically approximately when farmers stop inseminating cows. The interval of $525 \mathrm{~d}$ was chosen for hazard of death/cull because that is when cows that got pregnant at 305 DIM would be dried off $(305+220)$. The models included the fixed effects of CXCR1c.735 genotype, parity, RFM, metritis, END, mastitis, 2-way interactions between CXCR1c.735 and other covariates, and herd as a random effect. Because the CXCR1c.735 genotype was associated with incidence rate of clinical mastitis, and mastitis was associated with the hazard of pregnancy and the hazard of death or cull, a model that excluded mastitis was run to evaluate the possibility of mastitis acting as an intermediary variable on the effect of CXCR1c.735 genotype on the hazard of pregnancy and death or cull. The Weibull and Lognormal survival distributions were compared and the gamma and inversed Gaussian distribution of the frailties were compared; however, the results were very similar. Therefore, the Weibull survival distribution with the gamma frailty distribution is presented here. The median days to pregnancy or death/cull were obtained by survival analysis from the Kaplan-Meier model using the LIFETEST procedure of SAS. The survival plots were generated using the survival option of MedCalc (MedCalc Software, Mariakerke, Belgium).

For all statistical tests, a 2-sided hypothesis was considered. For all models, a hierarchical backward elimination was performed; variables were manually removed when $P>0.10$. Differences with $P \leq 0.05$ were considered significant and those with $0.05<P$ $\leq 0.10$ were considered as tending toward statistical difference.

\section{RESULTS}

Frequency of genotypes CC, GC, and GG were 22.3, 49.7 , and $28.0 \%$, and tended $(P=0.06)$ to be different between primiparous and multiparous cows $(16.3,55.1$, and $28.6 \%$ vs. $26.6,45.8$, and $27.6 \%$ ) mainly because of decreased frequency of genotype $\mathrm{CC}$ and increased frequency of genotype $\mathrm{GC}$ in primiparous compared with multiparous cows. Of the 350 cows, 36 (10.3\%) were diagnosed with RFM, $86(24.6 \%)$ were diagnosed with metritis, and $125(35.7 \%)$ were diagnosed with
END. Mean and median day of diagnosis of metritis was $6 \mathrm{~d}$ after calving, with a range from 2 to $14 \mathrm{~d}$ after calving.

The CXCR1c.735 genotype was not associated with $\operatorname{RFM}(P=0.95$; Table 1$)$, metritis $(P=0.31$; Table 1$)$, or END $(P=0.88$; Table 1$)$. Retained fetal membranes were only associated with parity, with a tendency toward significance for multiparous cows to have greater incidence than primiparous cows $[12.8$ vs. $6.8 \%$; odds ratio $(\mathbf{O R})=2.1 ; P=0.07 ;$ Table 1$]$. Metritis was associated with parity and RFM; multiparous cows had decreased incidence of metritis compared with primiparous cows (18.2 vs. $32.0 \%$; OR $=0.4 ; P=0.002$; Table 1) and cows that did not have RFM had decreased incidence of metritis compared with cows that had RFM (21.0 vs. $50.0 \%$; OR $=0.2 ; P<0.001$; Table 1 ). Endometritis was only associated with RFM; cows that did not have RFM had decreased prevalence of END compared with cows that had RFM (32.5 vs. $63.9 \%$; $\mathrm{OR}=0.3 ; P<0.001 ;$ Table 1$)$.

Incidence rate of clinical mastitis was associated $(P$ $=0.05)$ with CXCR1c.735 genotype (Table 2); cows with genotypes $\mathrm{CC}$ and GC had decreased $(P \leq 0.05)$ incidence rate of clinical mastitis compared with GG cows (12.3 vs. 13.2 vs. 21.9 cases per 10,000 cow-days at risk). Mastitis was also associated with parity; multiparous cows had greater incidence rate of clinical mastitis than did primiparous cows (22.6 vs. 10.3 cases per 10,000 cow-days at risk; $P<0.001$; Table 2).

Somatic cell count was not associated $(P=0.33)$ with CXCR1c.735 genotype (Table 3). Somatic cell count was associated $(P<0.05)$ with parity and mastitis. Multiparous cows had greater $\operatorname{lnSCC}$ than primiparous $(5.1 \pm 0.1$ vs. $4.6 \pm 0.1 \operatorname{lnSCC}$; Table 3$)$, and cows that had mastitis had greater lnSCC than cows that did not have mastitis $(5.5 \pm 0.1$ vs. $4.1 \pm 0.1 \operatorname{lnSCC}$; Table 3). Milk test also affected lnSCC: the LnSCC was highest in the first milk test, lowest in the second, and then increased steadily to the level of the first test by the tenth milk test (Table 3). Somatic cell count was not associated $(P=0.38)$ with CXCR1c.735 genotype, even when mastitis was excluded from the model. After excluding mastitis from the model, $\mathrm{CC}$ cows had the lowest $\operatorname{lnSCC}, \mathrm{CG}$ cows had the highest, and GG cows were intermediate $(4.2 \pm 0.1$ vs. $4.4 \pm 0.1$ vs. $4.3 \pm 0.1$ $\operatorname{lnSCC}$ ).

Milk yield tended to be associated $(P=0.06)$ with CXCR1c.735 genotype (Table 4); cows with genotype GC had greater milk yield than GG cows $(39.3 \pm 0.3$ vs. $38.0 \pm 0.4 \mathrm{~kg} / \mathrm{d} ; P=0.02) ; C C$ cows were intermediate $(38.7 \mathrm{~kg} / \mathrm{d})$. As expected, multiparous cows produced more milk than primiparous cows ( 40.9 vs. $36.4 \mathrm{~kg} / \mathrm{d}$; $P<0.001$ ); especially in the first 7 monthly milk tests (interaction between parity and milk test; $P<0.001$ ). 
Table 1. Final mixed logistic regression models for the incidence of the uterine diseases retained fetal membranes (RFM), metritis, and endometritis (END)

\begin{tabular}{|c|c|c|c|c|c|c|c|}
\hline Disease & Variable $^{1}$ & Level & $\begin{array}{c}\text { Cows, } \\
\mathrm{n}\end{array}$ & $\begin{array}{c}\text { Affected } \\
\%\end{array}$ & $\begin{array}{l}\text { Odds } \\
\text { ratio }\end{array}$ & $\begin{array}{c}95 \% \\
\text { CI }\end{array}$ & $P$-value ${ }^{2}$ \\
\hline \multirow[t]{5}{*}{$\mathrm{RFM}$} & \multirow[t]{3}{*}{ CXCR1c.735 } & $\mathrm{CC}$ & 78 & 11.5 & 1.2 & $0.4-3.1$ & 0.78 \\
\hline & & $\mathrm{GC}$ & 174 & 10.3 & 1.1 & $0.5-2.7$ & 0.77 \\
\hline & & GG & 98 & 9.2 & - & - & - \\
\hline & \multirow[t]{2}{*}{ Parity } & Multiparous & 203 & 12.8 & 2.1 & $0.9-4.5$ & 0.07 \\
\hline & & Primiparous & 147 & 6.8 & - & - & - \\
\hline \multirow[t]{7}{*}{ Metritis } & \multirow[t]{3}{*}{ CXCR1c.735 } & $\mathrm{CC}$ & 78 & 20.5 & 1.2 & $0.5-2.7$ & 0.64 \\
\hline & & $\mathrm{GC}$ & 174 & 27.6 & 1.6 & $0.9-3.0$ & 0.14 \\
\hline & & GG & 98 & 20.4 & - & - & - \\
\hline & \multirow[t]{2}{*}{ Parity } & Multiparous & 203 & 18.2 & 0.4 & $0.2-0.7$ & 0.002 \\
\hline & & Primiparous & 147 & 32.0 & - & - & - \\
\hline & \multirow[t]{2}{*}{ RFM } & No & 314 & 21.0 & 0.2 & $0.1-0.4$ & $<0.001$ \\
\hline & & Yes & 36 & 50.0 & - & - & - \\
\hline \multirow[t]{5}{*}{ END } & \multirow[t]{3}{*}{ CXCR1c.735 } & $\mathrm{CC}$ & 78 & 38.5 & 1.2 & $0.6-2.3$ & 0.63 \\
\hline & & $\mathrm{GC}$ & 174 & 36.2 & 1.0 & $0.6-1.8$ & 0.91 \\
\hline & & GG & 98 & 32.7 & - & - & - \\
\hline & \multirow[t]{2}{*}{ RFM } & No & 314 & 32.5 & 0.3 & $0.1-0.6$ & $<0.001$ \\
\hline & & Yes & 36 & 63.9 & - & - & - \\
\hline
\end{tabular}

${ }^{1}$ CXCR1c.735 = CXCR1 genotypes for SNP at position +735 .

${ }^{2}$ Main effect of genotype for RFM model: $P=0.95$; contrast CC vs. GC: $P=0.97$. Main effect of genotype for metritis model: $P=0.31$; contrast CC vs. GC: $P=0.42$. Main effect of genotype for endometritis model: $P=$ 0.88 ; contrast $\mathrm{CC}$ vs. GC: $P=0.66$.

Hazard of pregnancy was not associated $(P=0.89)$ with CXCR1c.735 genotype. Cows that had mastitis had decreased hazard of pregnancy compared with cows that did not have mastitis $(\mathrm{HR}=0.7 ; 95 \% \mathrm{CI}$ $=0.5-0.9 ; P=0.02)$. Median days to pregnancy was increased by $40 \mathrm{~d}$ in cows that had mastitis compared with cows that did not have mastitis (151 vs. 111 d; Figure 2). There was a tendency toward significance for cows that had endometritis to have decreased hazard of pregnancy compared with cows that did not have endometritis ( $\mathrm{HR}=0.8 ; 95 \% \mathrm{CI}=0.6-1.0 ; P=0.09$ ). Median days to pregnancy was increased by $25 \mathrm{~d}$ in cows that had END compared with cows that did not have endometritis (140 vs. 115 d). Hazard of pregnancy was not associated $(P=0.61)$ with CXCR1c.735 genotype even if mastitis was excluded from the model.

Hazard of death or culling was not associated $(P=$ 0.90) with CXCR1c.735 genotype. Multiparous cows had increased hazard of death or culling compared with primiparous cows $(\mathrm{HR}=3.0 ; 95 \% \mathrm{CI}=1.8-4.8 ; P$ $<0.001$ ). Mean (median not available for primiparous cows) days to death or cull were $79 \mathrm{~d}$ less for multiparous compared with primiparous cows (394 vs. $473 \mathrm{~d}$ ). Cows that had mastitis had increased hazard of death or cull compared with cows that did not have mastitis $(\mathrm{HR}=1.6 ; 95 \% \mathrm{CI}=1.1-2.4 ; P=0.02)$. Median days to death or cull were $54 \mathrm{~d}$ less for cows that had mastitis compared with cows that did not have mastitis (462 vs. $516 \mathrm{~d}$; Figure 3). Hazard of death or cull was not associated $(P=0.61)$ with CXCR1c.735 genotype, even when mastitis was excluded from the model.

\section{DISCUSSION}

High-producing dairy cows (Kehrli et al., 1989; Gilbert et al., 1993; Goff and Horst, 1997; Mallard et al., 1998 ) and especially cows that develop uterine disease (Cai et al., 1994; Kim et al., 2005; Hammon et al., 2006

Table 2. Final Poisson regression model for the incidence rate of clinical mastitis

\begin{tabular}{llccccc}
\hline Variable & Level & Cows, $\mathrm{n}$ & $\mathrm{IR}^{1}$ & $\mathrm{IRR}^{2}$ & 95\% CI & $P$-value \\
\hline CXCR1c.735 & CC & 78 & 12.3 & 0.6 & $0.3-1.0$ & 0.05 \\
& GC & 174 & 13.2 & 0.6 & $0.4-1.0$ & 0.04 \\
Parity & GG & 98 & 21.9 & $\overline{-}$ & - & - \\
& Multiparous & 203 & 22.6 & 2.2 & $1.4-3.4$ & $<0.001$ \\
\hline
\end{tabular}

${ }^{1}$ Incidence rate per 10,000 cow-days at risk.

${ }^{2}$ Incidence rate ratio.

${ }^{3}$ Main effect of genotype: $P=0.05$; contrast CC vs. GC: $P=0.80$.

${ }^{4} \mathrm{CXCR} 1$ genotypes for SNP at position +735 . 
GALVÃO ET AL.

Table 3. Final mixed model for natural logarithm of SCC (lnSCC)

\begin{tabular}{llcccc}
\hline Variable & Level & Cows, $\mathrm{n}$ & $\operatorname{lnSCC}$ & $95 \%$ CI & $P$-value $^{2}$ \\
\hline CXCR1c.735 & CC & 78 & $4.8 \pm 0.1$ & $4.6-5.0$ & 0.67 \\
& GC & 174 & $4.9 \pm 0.1$ & $4.8-5.1$ & 0.15 \\
Parity & GG & 98 & $4.8 \pm 0.1$ & $4.6-4.9$ & - \\
& Multiparous & 203 & $5.1 \pm 0.1$ & $4.9-5.2$ & $<0.001$ \\
Mastitis & Primiparous & 147 & $4.6 \pm 0.1$ & $4.4-4.8$ & - \\
& Yes & 101 & $5.5 \pm 0.1$ & $5.3-5.8$ & $<0.001$ \\
Milk test & No & 249 & $4.1 \pm 0.1$ & $4.0-4.2$ & - \\
& 1 & 336 & $5.3 \pm 0.1$ & $5.1-5.5$ & 0.48 \\
& 2 & 328 & $4.5 \pm 0.1$ & $4.3-4.7$ & $<0.001$ \\
& 3 & 315 & $4.7 \pm 0.1$ & $4.5-4.9$ & $<0.001$ \\
& 4 & 307 & $4.6 \pm 0.1$ & $4.4-4.8$ & $<0.001$ \\
& 5 & 300 & $4.7 \pm 0.1$ & $4.5-4.9$ & $<0.001$ \\
& 6 & 290 & $4.7 \pm 0.1$ & $4.5-4.9$ & $<0.001$ \\
& 7 & 286 & $4.8 \pm 0.1$ & $4.6-5.0$ & 0.003 \\
& 8 & 284 & $4.8 \pm 0.1$ & $4.6-5.0$ & 0.002 \\
& 9 & 282 & $5.0 \pm 0.1$ & $4.8-5.2$ & 0.04 \\
\hline
\end{tabular}

${ }^{1} \mathrm{LSM} \pm \mathrm{SEM}$.

${ }^{2}$ Main effect of genotype: $P=0.33$; contrast CC vs. GC: $P=0.38$.

${ }^{3}$ CXCR1 genotypes for SNP at position +735 .

experience a decrease in neutrophil function around calving. Several factors can account for the loss in neutrophil function such as increases in blood estradiol and cortisol concentrations around calving, deficit in nutrients and minerals such as vitamins $\mathrm{A}$ and $\mathrm{E}$, calcium, and selenium (Goff and Horst, 1997; Hammon et al., 2006; Kimura et al., 2006; Rutigliano et al., 2008). This study evaluated the role of CXCR1c.735 genotype on incidence of uterine diseases (RFM, metritis, and END) and mastitis, and evaluated reproductive performance, milk yield, and survival in cows with different genotypes. Identification of genetic markers could lead to selection of cows that are resistant to uterine disease or mastitis and possibly improve reproductive performance, production, and survival.
Although neutrophils with CXCR1c.735 genotypes $\mathrm{CC}$ and GC have impaired migration and decreased generation of reactive oxygen species (Rambeaud and Pighetti, 2005; Rambeaud et al., 2006), no association between CXCR1c.735 genotype and incidence of RFM, incidence of metritis, and prevalence of END was observed in this study. Because neutrophil migration and function is equally important for bacterial clearance in the mammary gland as for bacterial clearance in the uterus and release of the fetal membranes, it seemed plausible that uterine health could also be compromised in cows with altered CXCR1c.735 genotype. Nonetheless, the results indicate that the uterus is not as sensitive to alterations in CXCR1 as the mammary gland. It is possible that other factors such as levels of IL-8

Table 4. Final mixed model for milk yield

\begin{tabular}{llcccc}
\hline Variable & Level & Cows, $\mathrm{n}$ & Milk $^{1}$ & 95\% CI & $P_{\text {-value }}{ }^{2}$ \\
\hline CXCR1c.735 & GC & 78 & $38.7 \pm 0.5$ & $37.8-39.6$ & 0.28 \\
& GC & 174 & $39.3 \pm 0.3$ & $38.7-39.9$ & 0.02 \\
Parity & GG & 98 & $38.0 \pm 0.4$ & $37.2-38.8$ & - \\
& Multiparous & 203 & $40.9 \pm 0.3$ & $40.3-41.5$ & $<0.001$ \\
Milk test & Primiparous & 147 & $36.4 \pm 0.4$ & $35.7-37.1$ & - \\
& 1 & 336 & $31.3 \pm 0.6$ & & \\
& 2 & 328 & $42.1 \pm 0.5$ & & \\
& 3 & 315 & $42.0 \pm 0.5$ & & \\
& 4 & 307 & $43.0 \pm 0.5$ & & \\
& 5 & 300 & $41.8 \pm 0.5$ & & \\
Parity $\times$ milk test & 6 & 290 & $40.3 \pm 0.5$ & & $<0.001$ \\
\hline
\end{tabular}

${ }^{1}$ Milk yield, $\mathrm{kg}, \mathrm{LSM} \pm \mathrm{SEM}$.

${ }^{2}$ Main effect of genotype: $P=0.06$; contrast CC vs. GC: $P=0.32$.

${ }^{3} \mathrm{CXCR} 1$ genotypes for SNP at position +735 . 




Figure 2. Time to pregnancy for cows that had mastitis (dashed line; median days to pregnancy $=151$ ) or did not have mastitis ( line; median days to pregnancy $=111$ ).

at the fetal and maternal placental interface (Kimura et al., 2002), binding of IL-8 to CXCR2, or chemotaxis induced by complement fractions could compensate for defects in CXCR1 (Gerard and Gerard, 1994; Höpken et al., 1996). Alternatively, other metabolic effects such as negative energy balance may overwhelm effects of CXCR1c.735 genotype on uterine health (Hammon et al., 2006; Huzzey et al., 2007). Primiparous cows and cows that have RFM are known to be at greater risk for metritis (Curtis et al., 1985; Goshen and Shpigel, 2006). In the present study, RFM was identified as a risk factor for END, which agrees with previous reports (Rutigliano et al., 2008). The interactions among uterine disease and parity are complex. Although multiparous cows have greater incidence of RFM, they have decreased incidence of metritis and similar incidence of END compared with primiparous cows (Galvão et al., 2009a,b).

Cows with genotype $\mathrm{CC}$ and or GC were expected to have increased incidence of clinical mastitis, but were actually found to have a decreased incidence rate compared with cows with genotype GG. This was a surprising finding given the impairment in neutrophil migration, the decreased generation of neutrophil reactive oxygen species observed in cows with genotype $\mathrm{CC}$ and GC (Rambeaud and Pighetti, 2005; Rambeaud et al., 2006), and the increased incidence of mastitis in cows with genotype CC (Youngerman et al., 2004b). Nonetheless, it is plausible to speculate that although a strong innate immune response is necessary to clear bacterial infection, such a response would also be inclined to cause the overt clinical signs used to diagnose clinical mastitis such as presence of abnormal milk (presence of flakes or clots, or discolored or watery milk) or abnormal udder (swollen or hard quarters). Although Youngerman et al. (2004b) did not observe significant differences among CXCR1c.735 genotypes, Holstein cows with genotype GG tended to have greater incidence of clinical mastitis than $\mathrm{CC}$ cows, which agrees with the current findings. In contrast to Youngerman et al. (2004b), no difference in $\operatorname{lnSCC}$ among CXCR1c.735 genotypes was observed in the present study, whose results were similar to those of Leyva-Baca et al. (2008). As expected, multiparous cows had a greater incidence rate of clinical mastitis and greater $\operatorname{lnSCC}$ than primiparous cows (Bodoh et al., 1976; Kennedy et al., 1982; Breen et al., 2009), and cows that had mastitis had greater $\operatorname{lnSCC}$ than cows that did not have mastitis (Harmon, 1994; Pösö and Mäntysaari, 1996). Variation of lnSCC through time is also in accordance with previous reports (Wiggans and Shook, 1987).

Cows with genotype GG had decreased milk yield compared with CC and GC cows, although the difference was significant only for GC cows compared with GG cows. Youngerman et al. (2004b) also observed decreased milk yield for GG cows. Decreased milk yield for GG cows might be a consequence of increased incidence of clinical mastitis, which is known to reduce milk yields (Houben et al., 1993; Bar et al., 2007. Although CC cows also had decreased incidence of clinical mastitis compared with GG cows, greater incidence of subclinical mastitis (Youngerman et al., 2004b) could have impaired milk yield in cows with genotype CC.

Hazard of pregnancy was affected by mastitis and endometritis but not by CXCR1c.735 genotype. The absence of an effect of CXCR1c.735 genotype might be a result of the lack of association between CXCR1c.735 genotype and major uterine diseases that affect fertility

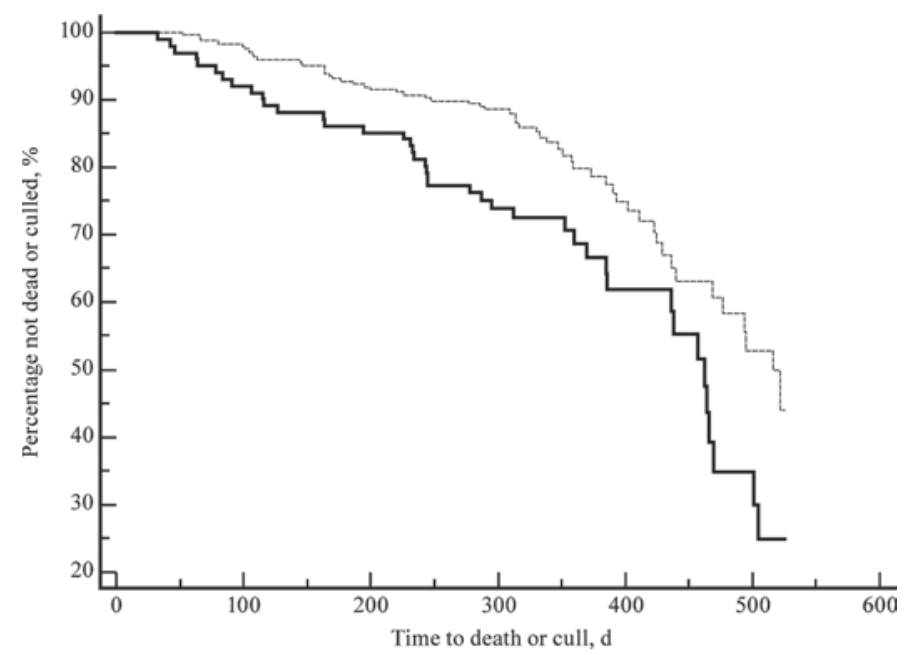

Figure 3. Time to death or cull for cows that had mastitis (solid line; median days to death or cull $=462$ ) or cows that did not have mastitis (dashed line; median days to death or cull $=516$ ). 
such as RFM, metritis, and END (Chebel et al., 2004; Gilbert et al., 2005; Galvão et al., 2009a). Mastitis has long been recognized by producers as an important factor that negatively affects fertility in dairy cows and has recently been reaffirmed (Chebel et al., 2004; Santos et al., 2004; Wilson et al., 2008; Hertl et al., 2010). Therefore, although a decrease in hazard of pregnancy in cows with genotype GG would be expected because of the observed increase in incidence rate of clinical mastitis and the decrease in hazard of pregnancy in cows that had mastitis, a direct association between CXCR1c.735 genotype and hazard of pregnancy was not observed.

Frequency of CXCR1c.735 genotypes in Holstein cows followed the same pattern as in previous reports (Youngerman et al., 2004a,b; Leyva-Baca et al., 2008). Surprisingly, primiparous cows had decreased prevalence of genotype CC and increased prevalence of genotype GC. This difference could arise from an increase in survival in primiparous cows with genotype CC. The survival analysis did not indicate a survival advantage for any of the genotypes. Again, although cows that had mastitis had decreased survival, a direct association between CXCR1c.735 genotype and cow survival was not observed. Parity and mastitis are known factors that affect mortality and culling in dairy cows (Bar et al., 2008).

\section{CONCLUSIONS}

In conclusion, uterine health was not affected by CXCR1c.735 genotype, which indicates that the uterus is not as sensitive to alterations in CXCR 1 as the mammary gland. Factors such as DMI and energy balance might be more important than CXCR1c.735 genotype for occurrence of uterine disease. Alternatively, factors such as concentration of IL-8 in the uterus, chemotaxis induced by complement split products, and binding of IL-8 to CXCR2 might compensate for the change in CXCR1. The CXCR1c.735 genotype was confirmed as an important factor for mammary gland health because cows with genotype GG had increased incidence rate of clinical mastitis and decreased milk yield compared with cows with genotypes GC and CC. The increased incidence rate of clinical mastitis in GG cows may be caused by a strong inflammatory response to infection, which might mediate development of overt clinical signs such as abnormal milk and udder quarters. Although CXCR1c.735 genotype did not affect hazard of pregnancy or survival, increased incidence rate of clinical mastitis in cows with genotype GG indicates a possible indirect negative effect on hazard of pregnancy and survival because cows that had mastitis had decreased hazard of pregnancy and survival. In summary, the CX-
CR1c.735 genotype GG (the genotype most common in other species) unexpectedly resulted in increased incidence rate of clinical mastitis and decreased milk yield.

\section{ACKNOWLEDGMENTS}

This project was supported, in part, by Pfizer Animal Health (New York, NY) and, in part, by the Cornell University Agricultural Experiment Station federal formula funds (Animal Health) Project No. NYC-480861 received from the Cooperative State Research, Education, Education and Extension Services, US Department of Agriculture. Any opinions, findings, conclusion, or recommendations expressed in the publication are those of the authors and do not necessarily reflect the view of the USDA. The authors thank the owners and staff of the collaborating dairies for allowing the use of their cows for this study. We extend our gratitude to Marta Castelhano and Liz Corey from the DNA bank at Cornell University (Ithaca, NY) for helping with DNA isolation.

\section{REFERENCES}

Bar, D., Y. T. Gröhn, G. Bennett, R. N. González, J. A. Hertl, H. F. Schulte, L. W. Tauer, F. L. Welcome, and Y. H. Schukken. 2007. Effect of repeated episodes of generic clinical mastitis on milk yield in dairy cows. J. Dairy Sci. 90:4643-4653.

Bar, D., Y. T. Gröhn, G. Bennett, R. N. González, J. A. Hertl, H. F. Schulte, L. W. Tauer, F. L. Welcome, and Y. H. Schukken. 2008. Effects of repeated episodes of generic clinical mastitis on mortality and culling in dairy cows. J. Dairy Sci. 91:2196-2204.

Bodoh, G. W., W. J. Battista, and L. H. Schultz. 1976. Variation in somatic cell counts in Dairy Herd Improvement milk samples. J. Dairy Sci. 59:1119-1123.

Breen, J. E., M. J. Green, and A. J. Bradley. 2009. Quarter and cow risk factors associated with the occurrence of clinical mastitis in dairy cows in the United Kingdom. J. Dairy Sci. 92:2551-2561.

Cai, T. Q., P. G. Weston, L. A. Lund, B. Brodie, D. J. McKenna, and W. C. Wagner. 1994. Association between neutrophil functions and periparturient disorders in cows. Am. J. Vet. Res. 55:934-943.

Chebel, R. C., J. E. Santos, J. P. Reynolds, R. L. Cerri, S. O. Juchem, and M. Overton. 2004. Factors affecting conception rate after artificial insemination and pregnancy loss in lactating dairy cows. Anim. Reprod. Sci. 84:239-255.

Cheong, S. H., D. V. Nydam, K. N. Galvão, B. M. Crosier, and R. O. Gilbert. 2011. Cow-level and herd-level risk factors for subclinical endometritis in lactating Holstein cows. J. Dairy Sci. 94:762-770. doi:10.3168/jds.2010-3439.

Curtis, C. R., H. N. Erb, C. J. Sniffen, R. D. Smith, and D. S. Kronfeld. 1985. Path analysis of dry period nutrition, postpartum metabolic and reproductive disorders, and mastitis in Holstein cows. J. Dairy Sci. 68:2347-2360.

Damaj, B. B., S. R. McColl, K. Neote, S. Q. Na, K. T. Ogborn, C. A. Hebert, and P. A. Naccache. 1996. Identification of g-protein binding sites of the human interleukin- 8 receptors by functional mapping of the intracellular loops. FASEB J. 10:1426-1434.

den Dunnen, J. T., and S. E. Antonarakis. 2000. Mutation nomenclature extensions and suggestions to describe complex mutations: A discussion. Hum. Mutat. 15:7-12.

Galvão, K. N., M. J. B. Flaminio, S. B. Brittin, R. Sper, M. Fraga, L. Caixeta, A. Ricci, C. L. Guard, W. R. Butler, and R. O. Gilbert. 2010. Association between uterine disease and indicators of neu- 
trophil and systemic energy status in lactating Holstein cows. J. Dairy Sci. 93:2926-2937.

Galvão, K. N., M. Frajblat, S. B. Brittin, W. R. Butler, C. L. Guard, and R. O. Gilbert. 2009b. Effect of prostaglandin F2alpha on subclinical endometritis and fertility in dairy cows. J. Dairy Sci. 92:4906-4913.

Galvão, K. N., L. F. Greco, J. M. Vilela, M. F. Sá Filho, and J. E. P. Santos. 2009a. Effect of intrauterine infusion of ceftiofur on uterine health and fertility in dairy cows. J. Dairy Sci. 92:1532-1542.

Gerard, C., and N. P. Gerard. 1994. C5A anaphylatoxin and its seven transmembrane-segment receptor. Annu. Rev. Immunol. 12:775808.

Gilbert, R. O., Y. T. Gröhn, P. M. Miller, and D. J. Hoffman. 1993. Effect of parity on periparturient neutrophil function in dairy cows. Vet. Immunol. Immunopathol. 36:75-82.

Gilbert, R. O., N. R. Santos, K. N. Galvão, S. B. Brittin, and H. B. Roman. 2007. The relationship between postpartum uterine bacterial infection (BI) and subclinical endometritis (SE). J. Dairy Sci. 90(Suppl. 1):469. (Abstr.)

Gilbert, R. O., S. T. Shin, C. L. Guard, H. N. Erb, and M. Frajblat. 2005. Prevalence of endometritis and its effects on reproductive performance of dairy cows. Theriogenology 64:1879-1888.

Goff, J. P., and R. L. Horst. 1997. Physiological changes at parturition and their relationship to metabolic disorders. J. Dairy Sci. 80:1260-1268.

Goshen, T., and N. Y. Shpigel. 2006. Evaluation of intrauterine antibiotic treatment of clinical metritis and retained fetal membranes in dairy cows. Theriogenology 66:2210-2218.

Gutierrez, R. G. 2002. Parametric frailty and shared frailty survival models. Stata J. 2:22-44.

Hammon, D. S., I. M. Evjen, T. R. Dhiman, J. P. Goff, and J. L. Walters. 2006. Neutrophil function and energy status in Holstein cows with uterine health disorders. Vet. Immunol. Immunopathol. 113:21-29.

Harmon, R. J. 1994. Physiology of mastitis and factors affecting somatic cell counts. J. Dairy Sci. 77:2103-2112.

Hertl, J. A., Y. T. Gröhn, J. D. Leach, D. Bar, G. J. Bennett, R. N. González, B. J. Rauch, F. L. Welcome, L. W. Tauer, and Y. H. Schukken. 2010. Effects of clinical mastitis caused by grampositive and gram-negative bacteria and other organisms on the probability of conception in New York State Holstein dairy cows. J. Dairy Sci. 93:1551-1560.

Höpken, U. E., B. Lu, N. P. Gerard, and C. Gerard. 1996. The C5a chemoattractant receptor mediates mucosal defense to infection. Nature 383:86-89.

Houben, E. H., A. A. Dijkhuizen, J. A. van Arendonk, and R. B. Huirne. 1993. Short- and long-term production losses and repeatability of clinical mastitis in dairy cattle. J. Dairy Sci. 76:2561-2578.

Hussain, A. M. 1989. Bovine uterine defense mechanisms: A review. Zentralbl. Veterinarmed. B. 36:641-651.

Huzzey, J. M., D. M. Veira, D. M. Weary, and M. A. von Keyserlingk. 2007. Prepartum behavior and dry matter intake identify dairy cows at risk for metritis. J. Dairy Sci. 90:3220-3233.

Kasimanickam, R., T. F. Duffield, R. A. Foster, C. J. Gartley, K. E. Leslie, J. S. Walton, and W. H. Johnson. 2004. Endometrial cytology and ultrasonography for the detection of subclinical endometritis in postpartum dairy cows. Theriogenology 62:9-23.

Kehrli, M. E. Jr., B. J. Nonnecke, and J. A. Roth. 1989. Alterations in bovine neutrophil function during the periparturient period. Am. J. Vet. Res. 50:207-214.

Kennedy, B. W., M. S. Sethar, A. K. W. Tong, J. E. Moxley, and B. R. Downey. 1982. Environmental factors influencing test-day somatic cell counts in Holsteins. J. Dairy Sci. 65:275-280.

Kim, I. H., K. J. Na, and M. P. Yang. 2005. Immune responses during the peripartum period in dairy cows with postpartum endometritis. J. Reprod. Dev. 51:757-764.

Kimura, K., J. P. Goff, M. E. Jr. Kehrli, and T. A. Reinhardt. 2002. Decreased neutrophil function as a cause of retained placenta in dairy cattle. J. Dairy Sci. 85:544-550.
Kimura, K., T. A. Reinhardt, and J. P. Goff. 2006. Parturition and hypocalcemia blunts calcium signals in immune cells of dairy cattle. J. Dairy Sci. 89:2588-2595.

Leyva-Baca, I., F. Schenkel, J. Martin, and N. A. Karrow. 2008. Polymorphisms in the $5^{\prime}$ upstream region of the CXCR 1 chemokine receptor gene, and their association with somatic cell score in Holstein cattle in Canada. J. Dairy Sci. 91:407-417.

Mallard, B. A., J. C. Dekkers, M. J. Ireland, K. E. Leslie, S. Sharif, C. L. Vankampen, L. Wagter, and B. N. Wilkie. 1998. Alteration in immune responsiveness during the peripartum period and its ramification on dairy cow and calf health. J. Dairy Sci. 81:585-595.

Mitchell, G. B., B. N. Albright, and J. L. Caswell. 2003. Effect of interleukin-8 and granulocyte colony-stimulating factor on priming and activation of bovine neutrophils. Infect. Immun. 71:1643-1649.

NRC. 2001. Nutrient Requirements of Dairy Cattle. 7th rev. ed. Natl. Acad. Sci. Washington, DC.

Paape, M. J., J. Mehrzad, X. Zhao, J. Detilleux, and C. Burvenich. 2002. Defense of the bovine mammary gland by polymorphonuclear neutrophil leukocytes. J. Mammary Gland Biol. Neoplasia $7: 109-121$.

Paape, M. J., K. Shafer-Weaver, A. V. Capuco, K. Van Oostveldt, and C. Burvenich. 2000. Immune surveillance of mammary tissue by phagocytic cells. Adv. Exp. Med. Biol. 480:259-277.

Pighetti, G. M., and M. Rambeaud. 2006. Genome conservation between the bovine and human interleukin- 8 receptor complex: Improper annotation of bovine interleukin- 8 receptor $\mathrm{b}$ identified. Vet. Immunol. Immunopathol. 114:335-340.

Pösö, J., and E. A. Mäntysaari. 1996. Relationships between clinical mastitis, somatic cell score, and production for the first three lactations of Finnish Ayrshire. J. Dairy Sci. 79:1284-1291.

Rabe-Hesketh, S., and A. Skrondal. 2008. Multilevel and Longitudinal Modeling Using Stata. 2nd ed. Stata Press Books. StataCorp LP, College Station, TX.

Rambeaud, M., R. Clift, and G. M. Pighetti. 2006. Association of a bovine CXCR2 gene polymorphism with neutrophil survival and killing ability. Vet. Immunol. Immunopathol. 111:231-238.

Rambeaud, M., and G. M. Pighetti. 2005. Impaired neutrophil migration associated with specific bovine CXCR2 genotypes. Infect. Immun. 73:4955-4959.

Rambeaud, M., and G. M. Pighetti. 2007. Differential calcium signaling in dairy cows with specific CXCR1 genotypes potentially related to interleukin- 8 receptor functionality. Immunogenetics 59:53-58

Rutigliano, H. M., F. S. Lima, R. L. A. Cerri, L. F. Greco, J. M. Vilela, V. Magalhães, F. T. Silvestre, W. W. Thatcher, and J. E. P. Santos. 2008. Effects of method of presynchronization and source of selenium on uterine health and reproduction in dairy cows. J. Dairy Sci. 91:3323-3336.

Santos, J. E., R. L. Cerri, M. A. Ballou, G. E. Higginbotham, and J. H. Kirk. 2004. Effect of timing of first clinical mastitis occurrence on lactational and reproductive performance of Holstein dairy cows. Anim. Reprod. Sci. 80:31-45.

Sheldon, I. M., G. S. Lewis, S. LeBlanc, and R. O. Gilbert. 2006. Defining post-partum uterine disease in cattle. Theriogenology 65:1516-1530.

Wiggans, G. R., and G. E. Shook. 1987. A lactation measure of somatic cell count. J. Dairy Sci. 70:2666-2672.

Wilson, D. J., Y. T. Grohn, G. J. Bennett, R. N. González, Y. H. Schukken, and J. Spatz. 2008. Milk production change following clinical mastitis and reproductive performance compared among J5 vaccinated and control dairy cattle. J. Dairy Sci. 91:3869-3879.

Youngerman, S. M., A. M. Saxton, S. P. Oliver, and G. M. Pighetti. 2004b. Association of CXCR2 polymorphisms with subclinical and clinical mastitis in dairy cattle. J. Dairy Sci. 87:2442-2448.

Youngerman, S. M., A. M. Saxton, and G. M. Pighetti. 2004a. Novel single nucleotide polymorphisms and haplotypes within the bovine CXCR2 gene. Immunogenetics 56:355-359. 